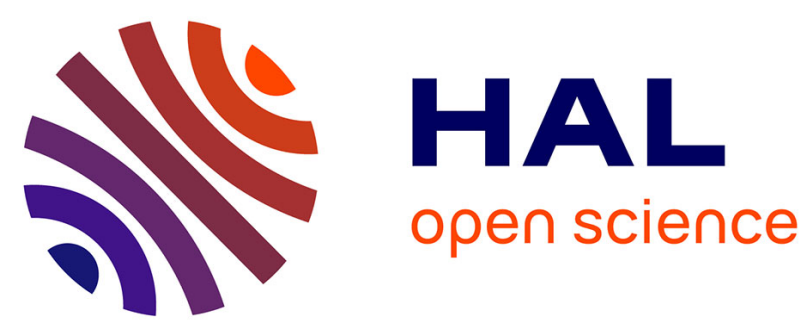

\title{
Testing of life history traits of a soilborne pathogen in vitro: Do characteristics of oospores change according the strains of Aphanomyces euteiches and the host plant infected by the pathogen?
}

Estelle Billard, Anne Quillévéré-Hamard, Clément Lavaud, Marie-Laure Pilet-Nayel, Christophe Le May

\section{To cite this version:}

Estelle Billard, Anne Quillévéré-Hamard, Clément Lavaud, Marie-Laure Pilet-Nayel, Christophe Le May. Testing of life history traits of a soilborne pathogen in vitro: Do characteristics of oospores change according the strains of Aphanomyces euteiches and the host plant infected by the pathogen? Journal of Phytopathology, 2019, 167 (6), pp.313-320. 10.1111/.jph.12799 . hal-02100057

\section{HAL Id: hal-02100057}

\section{https://institut-agro-rennes-angers.hal.science/hal-02100057}

Submitted on 15 Apr 2019

HAL is a multi-disciplinary open access archive for the deposit and dissemination of scientific research documents, whether they are published or not. The documents may come from teaching and research institutions in France or abroad, or from public or private research centers.
L'archive ouverte pluridisciplinaire HAL, est destinée au dépôt et à la diffusion de documents scientifiques de niveau recherche, publiés ou non, émanant des établissements d'enseignement et de recherche français ou étrangers, des laboratoires publics ou privés. 


\title{
Testing of life history traits of a soilborne pathogen in vitro: Do characteristics of oospores change according the strains of Aphanomyces euteiches and the host plant infected by the pathogen?
}

\author{
Estelle Billard $^{1}$ | Anne Quillévéré-Hamard ${ }^{1}$ | Clément Lavaud ${ }^{1}$ | \\ Maire Laure Pilet-Nayel ${ }^{1,2}$ | Christophe Le May ${ }^{1,2,3}$ (D)
}

${ }^{1}$ INRA, UMR 1349 Institut de Génétique, Environnement et Protection des Plantes (IGEPP), Domaine de la Motte, Le Rheu, France

${ }^{2}$ UMT PISOM, INRA/Terres Inovia, Le Rheu, France

${ }^{3}$ Agrocampus Ouest, UP Ecologie et Santé des Plantes (ESP), Rennes, France

\section{Correspondence}

Christophe Le May, INRA, UMR 1349 Institut de Génétique, Environnement et Protection des Plantes (IGEPP), Domaine de la Motte, Le Rheu, France.

Email: lemay@agrocampus-ouest.fr

Funding information

Research National Agency (ANR), Grant/

Award Number: ANR-11-BTBR-0002

\begin{abstract}
Aphanomyces euteiches is a polyphagous, homothallic soilborne pathogen producing asexual (zoospores) and sexual (oospores) spores. Even if oospores are essential for disease development and survival, to date, no study has focused on the production rates of oospores or the quality of the offspring produced by oospores. In this study, a nonabrasive oospore extraction method from infected roots of leguminous species (pea, faba bean and vetch) was developed. This methodology includes steps of grinding and filtration. The quality of oospores (viable, dormant and dead) was assessed with tetrazolium bromide staining, and germination of oospores was tested using exudates of peas, faba bean and vetch. The average yield of the extraction method was approximately $21 \%$. Staining revealed some differences between strains and between leguminous species. The germination percentage of oospores extracted from pea, faba bean and vetch was $25 \%, 62 \%$ and $70 \%$, respectively, and a significant difference was observed according to the origin of A. euteiches-inoculated strains. Application of exudates seems to stimulate the germination of oospores ( $2 \%$ for the control, $18 \%$ for pea exudates and $1 \%$ for vetch exudates). Differences observed between $A$. euteiches strains and leguminous species indicate that more knowledge concerning the biology of oospores is needed. This will help to better estimate evolution process of the pathogen and manage resistance and crop successions.
\end{abstract}

\section{KEYWORDS}

Aphanomyces, extraction, germination, oospores, viability

\section{1 | INTRODUCTION}

Aphanomyces euteiches is an oomycete pathogen that causes devastating root rot in many pea-growing countries, especially France. In Europe, A. euteiches was first observed in Norway in 1925 (Sundheim, 1972) and was reported a few years later in France (Labrousse, 1933), where it has been considered to be highly damaging in infested pea areas since 1993 (Didelot \& Chaillet, 1995). The increased frequency of peas in French crop rotations since 1978 favoured the development of the disease in all areas of pea production. To date, the disease has been recorded in pea-growing areas such as BassinParisien, Bretagne, Rhônes-Alpes, Pyrénées and Charente-Maritime regions. Initially considered to only be a pathogen of pea (Scott, 1961), A. euteiches was later reported to also infect other legume 
species including common bean, broad bean, faba bean, clover and alfalfa (Burnett, Coventry, Hirth, \& Greenhalgh, 1994; Greenhalgh \& Merriman, 1985; Lamari \& Bernier, 1985; Moussart, Even, \& Tivoli, 2008; Pfender \& Hagedorn, 1982; Tivoli, Baranger, Sivasithamparam, $\&$ Barbetti, 2006). It is a phenotypically and genotypically heterogeneous species (Grünwald \& Hoheisel, 2006; Malvick \& Percich, 1997; Le May et al., 2017; Quillévéré-Hamard et al., 2018). Aphanomyces euteiches is a diploid and homothallic pathogen producing both oospores (sexual reproduction) and zoospores (asexual reproduction; Grünwald \& Hoheisel, 2006). Oospores can survive in the soil for more than 10 years (Papavizas \& Ayers, 1974) and can resist unfavourable conditions (e.g., desiccation and freezing).

Currently, the primary methods to manage the disease in France include the avoidance of highly infested fields diagnosed using an inoculum potential test (Moussart et al., 2009) and crop rotations with non-host or resistant legume crops (Moussart, Even, Lesné, \& Tivoli, 2013). There are no cultivated resistant varieties but consistent Quantitative Trait Loci (QTL) controlling partial resistance have been identified, validated in pea (Desgroux et al., 2016; Lavaud et al., 2015) and used in French pea breeding programmes for the future development of resistant varieties. In order to support breeding for resistance against $A$. euteiches populations present in French pea-growing regions and better understand the potential adaptation of pathogen populations to genetic resistance, more knowledge is required about the ecology and genetic diversity of A. euteiches populations and factors influencing its potential evolution. The observation of only one pathotype in France (Le May et al., 2017; Quillévéré-Hamard et al., 2018) may facilitate breeding for resistance, but vigilance is required regarding the presence of other pathotypes. Indeed, a similar recommendation was already provided by Malvick and Grau (2001) to alfalfa breeders, because of the two races identified within alfalfa isolates. An adaptation event to host plant resistance (resistant to race 1 ) was described in alfalfa (Grau, Holub, \& Parke, 1991) suggesting that crop rotations will lead to the emergence of a new complex of pathogens.

Oospores are the main source of inoculum in soil (Bottin et al., 2008; Cannesan et al., 2011). They are sub-spherical and have a thick resistant wall (Bottin et al., 2008; Kraft, Marcinkowska, \& Muehlbauer, 1990) with a diameter between 20 and $23 \mu \mathrm{m}$ (Wicker, 2001). Oospore germination is induced by the presence of root exudates (Barton, 1957) and leads to the formation of filamentous sporangia (Gaulin, Jacquet, Bottin, \& Dumas, 2007; Wicker, 2001). The sporangium differentiates and releases 300-400 zoospores, the infectious unit of the pathogen, at the level of the apex (Bottin et al., 2008; Cannesan et al., 2011; Wicker, 2001). These bi-flagellated mobile elements encyst on the root surface before germinating and infecting the host (Bottin et al., 2008; Cannesan et al., 2011; Rosendahl, 1985). After a few days, the pathogen can reproduce sexually in the host and form new oospores (Bottin et al., 2008). These oospores representing the survival unit of A. euteiches can remain dormant in soil or organic debris for more than 10 years (Bottin et al., 2008; Cannesan et al., 2011; Grau, Peters, \& Shang, 2000; Rosendahl, 1985; Wicker, 2001). Except the study of Kraft and Boge (1996) showing variation in oospore production between resistant and susceptible cultivars, no studies have actually examined other associated life history traits of this pathogen. Except two recent studies using GPCR to quantify the mycelium amount of $A$. euteiches within infected pea roots (Larsen, Massfield-Giese, \& Bodker, 2000; Lavaud et al., 2015; Vandemark $\&$ Grünwald, 2004), no other studies on the other life history traits of the pathogens, such as the rate of oospore production (Grau et al., 2000) or the quality of the descendants released by these oospores have been reported. Oospores are very important structures in the life cycle of $A$. euteiches as they ensure the transfer of genetic information to the offspring and permit survival of the pathogen. As oospores constitute the central element of the epidemic cycle of A. euteiches, it is important to have a methodology allowing for the extraction of these structures from infected roots. Better knowledge of the production rate of oospores and germination potential of oospores is essential and will allow us to better estimate the evolutionary potential of this pathogen and improve management of plant resistance.

The objective of this work was (a) to develop a nonabrasive methodology for extracting oospores, (b) to estimate the quality (number of living/ dead/ latent oospores) of extracted oospores using a colorimetric methodology and (c) to define the germination potential of oospores.

\section{2 | MATERIALS AND METHODS}

\section{1 | Aphanomyces euteiches strains}

Five strains of $A$. euteiches were used in this study. Three French strains (Rb84, C6, and B2) belonged to pathotype I (Le May et al., 2017), and two U.S. strains (MF1 and Ae109) belonged to pathotype III (Wicker, Hulle, \& Rouxel, 2001). These five strains were isolated from infested peas and stored on a sterile Corn Meal Agar media at $10^{\circ} \mathrm{C}$.

\section{2 | Plant material}

Pathogenicity tests were conducted on three cultivars of three leguminous species that previously showed varying levels of resistance to the Rb84 strain (Moussart et al., 2008). Plant genotypes included the following: pea (Pisum sativum) cv. Lumina (susceptible, Nickerson, France), faba bean (Vicia faba) cv. Baraca (moderately susceptible, Agrovegetal SA, Spain) and vetch (Vicia sativa) cv. Amethyste (susceptible, Jouffray-Drillaud, France). Each experiment included four replicates of four to five plants per cultivar and isolate tested. Each experiment was repeated once. Seeds were sown in plastic pots $(9 \times 9 \times 9.5 \mathrm{~cm})$ containing unsterilized vermiculite (VERMEX, M). Faba bean seeds were soaked in water for $2 \mathrm{hr}$ before sowing. In each pot, five seeds of one pea, vetch or alfalfa cultivar, and four seeds of one faba bean cultivar were sown. Each pot constituted a replicate. Pots were placed in a randomized design in a growth chamber (thermo period: $25 / 23^{\circ} \mathrm{C}$ and 16 -hr photoperiod). 


\section{3 | Inoculum production and evaluation of disease reactions}

Seven days after sowing, each plant was inoculated by applying $5 \mathrm{ml}$ of a zoospore suspension adjusted to $5 \times 10^{3}$ spores $/ \mathrm{ml}$, as previously described by Moussart, Wicker, Duparque, and Rouxel (2001). After inoculation, the vermiculite was saturated with water to provide favourable conditions for infection. After 10 days, the plants were carefully removed from the vermiculite, roots were washed in tap water and disease severity (DS) was scored on each plant using a 0-5 scoring scale (Moussart et al., 2007): 0 = no symptom; 1 = traces of discoloration on the roots (<25\%); 2 = discoloration of $25 \%-50 \%$ of the roots; 3 = discoloration of $50 \%-75 \%$ of the roots; $4=$ discoloration of $>75 \%$ of the roots; $5=$ plant dead.

\section{4 | Oospores extraction}

Methodology used was adapted from Kraft and Boge (1996). Several steps were considered to extract oospores from infected roots: crushing, filtration and oospores counting.

\subsection{1 | Crushing}

For each method, fifteen infested roots were cut with a sterilized scalpel and then transferred to a grinder (Blender). Crushing was tested by adding, or not, enzymes. For each condition of the test, $5 \mathrm{ml}$ of non-sterile cold water was added to the grinder. Then the volume was either supplemented with $6 \mathrm{ml}$ of sterile osmosis water, $6 \mathrm{ml}$ of an enzyme mixture $(3 \mathrm{ml}$ of cellulase and $3 \mathrm{ml}$ of pectinex (polygalacturonase), $0.5 \mathrm{mg} / \mathrm{ml}$ of each). Crushing was performed for 1 min (fast speed), and to avoid the loss of material, the ground material was collected by rinsing the grinder with $9 \mathrm{ml}$ of sterile water. Finally, a sonication ( $1 \mathrm{~min}$ at $35 \mathrm{~Hz}$ ) was performed to separate the oospores from the mycelium. The root samples treated with the enzymes were finally incubated at room temperature for $24 \mathrm{hr}$ under agitation (250 rpm) to promote enzymatic digestion.

\subsection{2 | Filtration}

Two methods were tested to separate the oospores from the root debris: (a) a vacuum filtration and (b) a filtration using a sucrose gradient. For the first method, a $20 \mathrm{ml}$ solution of ground material was filtered under vacuum through two successive filters $(150 \mu \mathrm{m}$ then $60 \mu \mathrm{m}$ diameter, Glass Microfiber Filter, Whatman) to remove a maximum of debris. To avoid the loss of oospores due to debris accumulation, the Filler was rinsed with $20 \mathrm{ml}$ of sterile water by removing the coarser fragments. Finally, the solution was filtered through a final $10 \mu \mathrm{m}$ filter to retain the oospores. To recover the oospores, the final filter was rinsed with $2 \mathrm{ml}$ of sterile water. For the second method, a solution containing $0 \%$ sugar, $20 \%$ then $60 \%$ sugar was prepared. The $20 \mathrm{ml}$ solution of ground material was gently added to the sucrose gradient to avoid the mixture of the different phases.
Then, this solution was incubated at room temperature to decant $24 \mathrm{hr}$. The upper phase containing the oospores was recovered in $2 \mathrm{ml}$ of solution.

\subsection{3 | Oospores counting}

To evaluate the extraction performance of each method, oospores concentration was assessed using a Malassez haemocytometer. Oospore counting was performed before and after different filtrations to evaluate yield.

\section{5 | Evaluation of oospore quality}

Filters containing oospores were introduced in $0.1 \%$ tetrazolium bromide (Sigma-Aldrich) in $1 \mathrm{mmol} \mathrm{I}^{-1}$ potassium phosphate buffer $(\mathrm{pH}=6.3)$ solution and incubated for $24 \mathrm{hr}$ at $35^{\circ} \mathrm{C}$ in $0.1 \%$ of thiazolyl blue tetrazolium bromide (MTT) contained in a potassium phosphate buffer ( $1 \mathrm{~mol} \mathrm{I}^{-1}, \mathrm{pH}=6.3$; Jiang \& Erwin, 1990). Filters were rinsed several times with deionized water, and then, samples were sonicated at $35 \mathrm{~Hz}$ for $90 \mathrm{~s}$ in $2 \mathrm{ml}$ sterile water to completely detach oospores from the filter. Extracted oospores were then microscopically (Olympus $\mathrm{CH} 40, \mathrm{x} 200$ ) examined. Oospores were classified as red-rose, blue, black or unstained. Oospores that stained red to rose were considered to be viable dormant (dormant), blue were viable activated (viable), and black and unstained non-viable (dead; Etxeberria, Larregla, \& Sorkunde, 2011).

\subsection{Roots exudates extraction and oospore germination assessment}

Root exudates were produced following the methodology described by Shang, Grau, and Peters (2000). Root exudates were produced from the legume species used in the initial experiment (pea, faba bean and vetch). Seeds of each species were rinsed in $95 \%$ ethanol, soaked in $0.2 \% \mathrm{HgCl}$ for $5 \mathrm{~min}$, and rinsed with sterile, deionized water three times. Seeds were placed in sterile glass flasks $(100 \mathrm{ml}$, 10 seeds per flask) containing $5 \mathrm{ml}$ of sterile, deionized water. Flasks were then covered with sterile aluminium foil and kept at room temperature in the dark for 14 days to allow germination and root development. To collect exudates, the cover was removed carefully and $5 \mathrm{ml}$ of a sterile lake water:deionized water mixture (1:1) was added. One hour after incubation at room temperature, the exudate solution from each flask was removed with a sterile Pasteur pipet and stored at $4^{\circ} \mathrm{C}$ (Shang et al., 2000). To test the effect of each root exudate on oospore germination, $1 \mathrm{ml}$ of each root exudate was delivered to each oospore solution placed on Petri dish containing CMA media so that the oospore was covered by the exudate. Dishes were incubated for 9 days at $24^{\circ} \mathrm{C}$. Germination was evaluated using a light microscope $(\times 100)$, assuming that an oospore was germinated if there was a germ tube at least half the diameter of the oospores, or if the sporangium was present (Shang et al., 2000; Widmer, 2010). 


\section{7 | Statistical analysis}

Statistical analysis was performed using the software $R(R$, version 2.13.0, Gentleman \& Ihaka, 1996). Statistical analysis was carried out in order to evaluate the impact of the oospore extraction method (grindings with and without enzymes, vacuum or sugar gradient filtrations) on extracted oospore amount. A Bartlett's test was performed to determine whether the variance in yield was the same for the per cent harvests homogeneous between the two repeated experiments (Bartlett's K-squared $=0.13489, d f=1, p$-value $=0.7134$ ) Oospore yield was considered as the explanatory variable and the extraction method as the factor. Then, for each extraction method, oospore yields were compared with the Tukey test ( $\alpha=5 \%$ ).

ANOVA was performed to evaluate the effect of $A$. euteiches isolate (Rb84, C6, B2, Ae109 and MF1) on the quality of oospore (live, dead, latency) extracted from different infested root systems (pea, faba bean and common vetch). For each host root system, a pairwise comparison was performed using the Tukey test ( $\alpha=5 \%$ ). A pairwise comparison, based on the oospore quality estimated on the different host root system, was performed between the different $A$. euteiches isolates.

Finally, the potential of oospore germination was studied for each $A$. euteiches isolates by comparing the potential germination of oospores not exposed to exudate, and oospores exposed to exudates extracted from different hosts (pea and vetch). Data were analysed using the non-parametric Mann-Whitney tests $(p<0.05)$.

\section{3 | RESULTS}

\section{1 | Oospores extraction and control of oospore quality}

In order to optimize the extraction of oospores, different protocols, combining grinding, enzymatic digestion, filtration and sonication were tested. Results showed significant differences between the methods used ( $p<0.001$; Figure 1). The amount of oospores extracted with method 1 (grinding with enzyme associated to vacuum filtration) and method 3 (grinding without enzymes associated to vacuum filtration) were significantly different from the yield of the two other methods including grinding step with or without enzyme digestion and filtrations on a sugar gradient $(p<0.001)$. Method 1 displayed an average yield of $21 \%$ against 4,14 and $2 \%$, respectively, for the other methods (Figure 1).

Colorimetric methodology was used to evaluate the quality of oospores extracted with the first methodology (method 1). In this experiment, different host plants and $A$. euteiches isolates were used to define if the quality of oospores could be influenced by these factors. Results showed that the percentages of viable and dormant oospores were significantly different between pea, faba bean and vetch species ( $p<0.001$; Figure 2). In particular, results showed a significant difference in the viability and dormancy status of oospores between oospores extracted from pea roots and those extracted from faba bean and vetch roots $(p<0.001)$. The

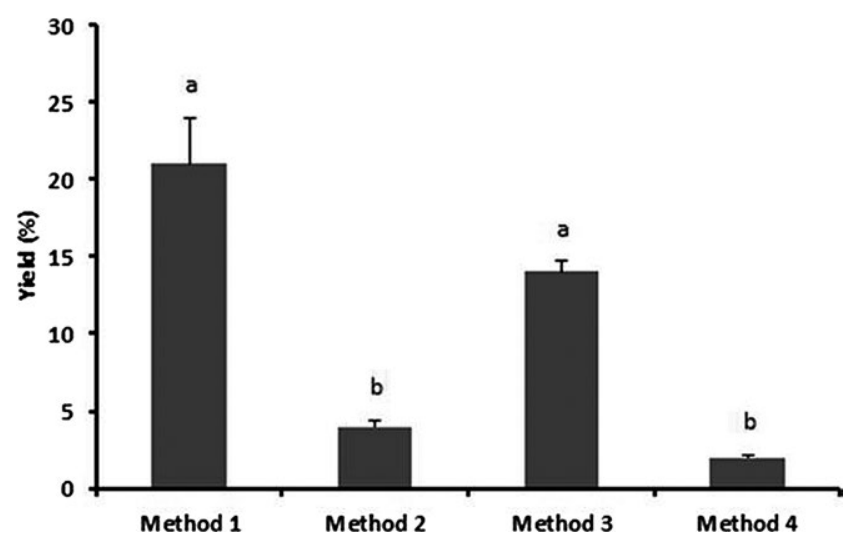

FIGURE 1 Efficiency (rate of losses between the different steps of filtration) of the four oospores extraction methodologies on pea root infested by Aphanomyces euteiches. Method 1: crushing with enzymes (cellulase, pectinex) and vacuum filtration; Method 2: crushing with enzymes and filtration using a sucrose gradient; Method 3: crushing without enzymes and vacuum filtration; Method 4: crushing without enzymes and filtration using a sucrose gradient

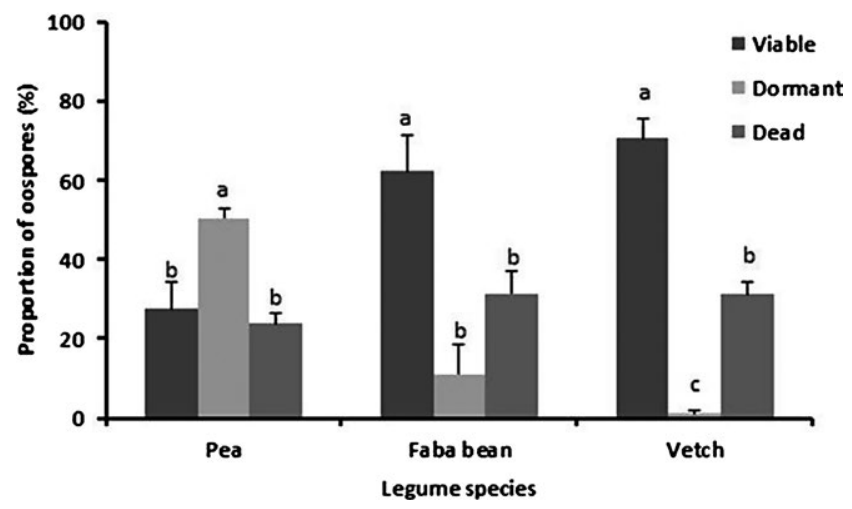

FIGURE 2 Mean percentage of the different type of oospores (dead, dormant, viable) extracted from roots of faba bean, pea and vetch infested by different strains of Aphanomyces euteiches (Rb84, C6, B2, Ae109, MF1)

highest percentage of viable oospores was observed on infested vetch roots (70\%), followed by infested faba bean roots (62\%), and infested pea roots (25\%). The percentage of dead oospores was not different between the different legume species $(p=0.3$; Figure 2).

The effect of A. euteiches strain origin was studied independently from the origin of root hosts. On infested pea roots (Figure 3a), a greater proportion of dormant oospores were observed (50\%) than viable and dead oospores. Ae109 strain showed a significantly $(p<0.001)$ lower proportion of viable oospores than other strains, and it also had the highest proportion of dead oospores among strains $(p<0.001)$. On infested faba bean roots, significant differences were observed among strains $(p<0.001$; Figure $3 b$ ). The proportion of viable and dormant oospores was significantly different between the strains of $A$. euteiches $(p<0.001)$. 
FIGURE 3 Comparison of the production of the different type of oospores (dead, dormant, viable) produced by the different strains of Aphanomyces euteiches inoculated on the legume species. (a) Pea roots, (b) faba bean roots, (c) vetch roots
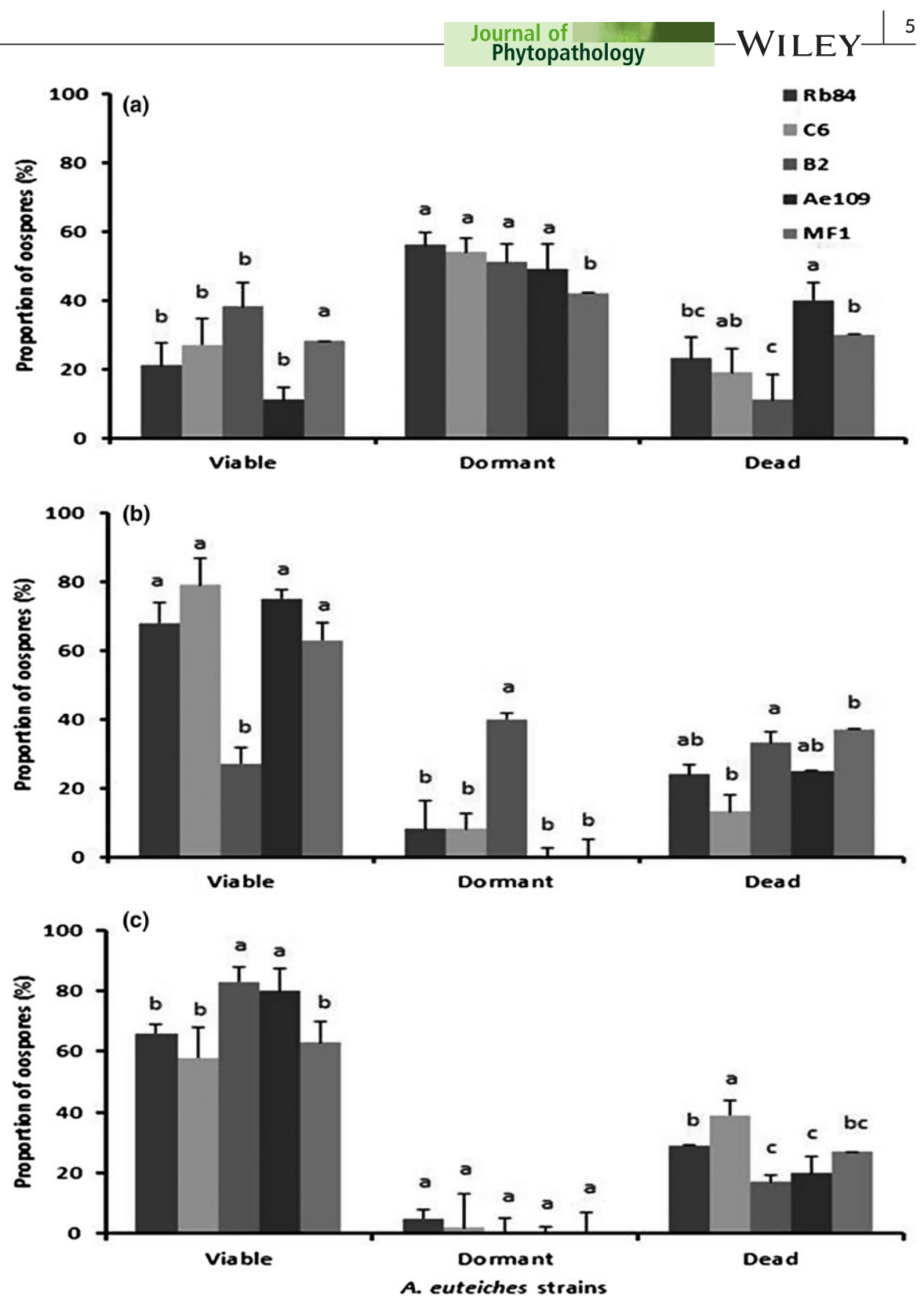

B2 strain showed a lower proportion of viable oospores and a higher proportion of dormant oospores $(p<0.001)$, whereas significant differences $(p<0.01)$ were observed between B2-MF1 and $\mathrm{C} 6$ strains. Similar to faba bean, infested vetch roots showed a higher proportion of viable oospores compared with dormant and dead oospores roots (Figure 3c). Significant differences among A. euteiches strains were observed for viable and dead oospores. B2 and Ae109 produced the highest proportion of viable oospores $(p<0.001)$, whereas C6 showed the highest proportion of dead oospores $(p<0.001)$ among strains.

\subsection{Effect of roots exudates origin on the germination potential of oospores}

Of the three root exudates tested (peas, vetch and faba bean), only pea root exudate showed a significantly different oospore germination rate than the water control (Mann-Whitney, $W=12, p=0.01$;
Table 1). Differences were also observed according to the origin of A. euteiches isolates. The isolate B2 had the highest percentage of germination for oospores stimulated with pea exudates (Table 1). Exudates extracted from faba bean roots were too low to observe any effect on oospores germination.

\section{4 | DISCUSSION}

The oospore extraction protocols tested in this work included grinding steps and filtrations. The purpose of this method was to extract oospores nonabrasively and for the first time directly from infected legume roots. The method that appeared to be the most efficient for extracting and recovering a large number of oospores is method 1 , which included grindings with enzymes and vacuum filtrations. Cellulase and pectinex enzymes can actively degrade plant tissues and detach oospores from mycelium that is found in greater 
TABLE 1 Effect of pea and vetch root exudates on the germination of oospores from the different Aphanomyces euteiches strains (Rb84, B2, C6, MF1, Ae109)

\begin{tabular}{|c|c|c|c|}
\hline Strains & Water & Pea root exudates & $\begin{array}{l}\text { Vetch root } \\
\text { exudates }\end{array}$ \\
\hline \multicolumn{4}{|c|}{ Percentage of germinated oospores } \\
\hline $\mathrm{Rb} 84$ & $5 \% \pm 2 \%$ & $14 \% \pm 2 \%$ & $4 \% \pm 2 \%$ \\
\hline C6 & $2 \% \pm 1 \%$ & $5 \% \pm 2 \%$ & $2 \% \pm 1 \%$ \\
\hline B2 & $2 \% \pm 1 \%$ & $66 \% \pm 2 \%^{a}$ & 0 \\
\hline Ae109 & 0 & $5 \% \pm 2 \%$ & 0 \\
\hline MF1 & 0 & 0 & 0 \\
\hline
\end{tabular}

${ }^{a}$ Significant difference on oospore germination rate between pea root exudate and the two other modalities (vetch root exudate and water control; Mann-Whitney, $W=12, p=0.01$ ).

quantity in the final extract (Hord \& Ristaino, 1991). This grinding step was previously used by Frinking and Van der Gaag (1996) to extract oospores of Peronospora viciae, a foliar pathogenic fungus of faba bean. These authors also showed that the addition of these enzymes did not affect the viability of oospores and that the following sonication step allowed a better separation of the oospores from the debris. Results showed that vacuum filtration led to higher yield than sugar gradient filtrations (Figure 1). The use of filters of 150 and $60 \mu \mathrm{m}$ helped eliminate a majority of root debris whereas filtration by decantation on sucrose gradient did not allow for the separation of oospores from debris. This could be due to the size of the oospores, similar to that of the root fragments, which would drag them into the pellet. However, the yield of the method still needs to be improved. The average yield was $21 \%$ compared with $75 \%$ for a method of extracting oospores from soil (Frinking \& Van der Gaag, 1997). The main methodology of our protocol was based on oospore extraction from faba bean leaves (Frinking \& Van der Gaag, 1997). Adapting the methodology to roots is difficult because of their resistant nature and structure. To improve the protocol, and more particularly reduce the amount of debris, it would be useful to test other methodology leading to a better decomposition of root system, such as a previous step of lyophilization before enzymatic digestion.

Improvement of this methodology is important for breeding programs. Consistent Quantitative Trait Loci (QTL) controlling partial resistances have been identified, validated in pea (Desgroux et al., 2016; Lavaud et al., 2015). However, no knowledge is available about the effect of the main resistance QTL on the disease development or A. euteiches life cycle, which could be used to support recommendations in QTL pyramiding strategies to durably increase partial resistance. Kraft and Boge (1996) reported that partial resistance to $A$. euteiches in pea breeding lines and germplasm was associated with reduced oospore production, pathogen multiplication, zoospore germination and slower lesion development. The genetic components of partial resistance targeting these pathogen life cycle steps were not identified. Precise A. euteiches quantification methods were developed for finer evaluation of pea resistance during pathogen development, including enzyme-linked immunosorbent assays, specific fatty acids analysis or, more recently, A. euteiches DNA quantification using Quantitative PCR (Kraft \& Boge, 1996; Larsen et al., 2000; Vandemark, Barker, \& Gritsenko, 2002; Vandemark \& Grunwald, 2005). These methods are highly sensitive, specifically to quantify the pathogen, but they are not useful for evaluating the impact of QTL on more advanced stages of disease development cycle. Sporulation, measurable as oospore number, is a key life history trait, essential for pathogen multiplication. Although our results showed a low efficiency of oospore extraction and that further optimization is required to improve the oospore extraction, it remains an important tool to study the effects of QTL on oospore viability.

\section{1 | Evaluation of oospore quality}

The second part of this work aimed to evaluate if the quality (viable, dormant or dead) of oospores extracted from infected roots would be affected by to the origin of the A. euteiches strain and the host plant. Result showed that host plant significantly affected the proportion of viable, dormant and dead oospores extracted from roots. Viable oospores represented $25 \%$, $62 \%$ and $70 \%$, respectively, on pea, faba bean and vetch. This result is quite surprising as more viable oospores were expected on pea. Indeed, all the $A$. euteiches-inoculated strains were more aggressive on pea than on the two other legume species (Quillévéré-Hamard et al., 2018). Concerning the impact of strain origin, difference between strains was observed for all the legume species. Differences were especially observed in the proportion of viable and dead oospores. This result suggests that the production and quality of oospores are more dependent on the origin and resistance level of the host plant than the origin of the strain. Two hypotheses can be proposed to explain this result. The resistance level of the three legume species used in this work led to a varying level of disease expression on roots. On pea root, only 4 days were required to obtain a necrosis root index score of 4 (disease scale $0-5$ ), while for both faba beans and vetch, 10 days were necessary to develop significant symptoms. Since the infected roots used for the oospores extraction were chosen based on their necrosis root index score, a methodological bias was introduced, and modification on the protocol is necessary. In order to exclude the potential hypothesis of trade-off between root colonization and production of living oospores, it would be interesting to assess the production of oospores and to evaluate their quality during the dynamic of the disease with host plant presenting a similar and a different resistance level towards the disease. The second explanation involves inconsistencies associated with the MTT staining method that have already been noted (Etxeberria et al., 2011) suggesting that the evaluation of oospore quality may be subjective. Finally, to validate the virulence of these oospores, it would be necessary to have a correlation between visual tests and the ability of oospores to induce disease (Dyer \& Windels, 2003). 


\subsection{Effect of the origin of root exudates on the germination capacity of oospores}

Tests showed differences in oospore germination according to the origin of exudates. Pea exudates led to a higher percentage of germinated oospores than the other two legume species. Differences were also observed between isolates as Rb84 and B2 isolates showed a higher number of germinated oospores. These results suggest that exudates contain specific host plant elements that induce oospore germination, and oospores will germinate for the root exudates of their principal host preferably (Grau et al., 2000). It is important to consider other factors that may influence germination such as oospore age, nutrient environment, temperature or light (Grau et al., 2000; Hord \& Ristaino, 1991). It is therefore not permissible at this stage to generalize our results without first making improvements to the protocol. For example, the counts performed may have been biased due to bacterial contaminations from root exudates. It should therefore be considered to use antibiotics associated with root exudates to overcome any contamination. Similarly, microscopic counting of Petri dishes is unreliable due to the random distribution of oospores on the medium. For that, it would be necessary to isolate the oospores to follow their germination. Once developed, these tests should provide useful information about the likely mode of germination of soil oospores.

\section{3 | Concluding remarks}

This study incorporated various approaches to improve knowledge on A. euteiches life history traits. Even if the methodology developed to extract the oospores from infected roots is not actually enough to correctly quantify the production of oospores, it led us to study the biological characteristics of oospores and will be helpful to screen new resistance sources. As oospores constitute a key point of the $A$. euteiches life cycle, it would be useful to better define the impact of resistance sources on the quality of oospores and their production. Improving the knowledge on the biology and ecology of $A$. euteiches would be a good strategy to better manage this disease.

\section{ACKNOWLEDGEMENTS}

This study was supported by INRA, AAP 2010 "Gestion Durable des Résistances," the PeaMUST project, which received funding from the French Government managed by the Research National Agency (ANR) under the Investments for the Future call 2011 (ANR-11-BTBR-0002). The authors greatly thank A. Moussart (Terres Inovia, UMT PISOM) for her valuable comments concerning the protocols and the experimental design, M-N. Even and C. Onfroy (Terres Inovia, UMT PISOM) for providing several isolates. We acknowledge the greenhouse and experimental device platform of IGEPP for providing and managing equipment for the experiments.

\section{AUTHOR CONTRIBUTIONS}

$\mathrm{EB}, \mathrm{CL}$ and $\mathrm{AQ}$ generated the phenotypic data. EB and CLM performed the statistical analyses, and CLM drafted the manuscript. CLM and MLPN coordinated and supervised the experiments. All the authors approved the final draft of the manuscript.

\section{ORCID}

Christophe Le May iD https://orcid.org/0000-0002-2421-7875

\section{REFERENCES}

Barton, R. (1957). Germination of oospores of Pythium mamillatum in response to exudates from living seedlings. Nature, 180, 613-614. https://doi.org/10.1038/180613a0

Bottin, A., Couloux, A., Dumas, B., Gaulin, E., Jacquet, C., Madoui, M. A., ... Wincker, P. (2008). Transcriptome of Aphanomyces euteiches: New oomycete putative pathogenicity factors and metabolic pathways. PloS ONE, 3(3), e1723. https://doi.org/10.1371/journal.pone. 0001723

Burnett, V. F., Coventry, D. R., Hirth, J. R., \& Greenhalgh, F. C. (1994). Subterranean clover decline in permanent pastures in north-eastern Victoria. Plant and Soil, 164, 231-241. https://doi.org/10.1007/ BF00010075

Cannesan, M. A., Driouich, A., Gangneux, C., Giron, D., Hawes, M., Lanoue, A., ... Vicré-Gibouin, M. (2011). Association between border cell responses and localized root infection by pathogenic Aphanomyces euteiches. Annals of Botany, 108, 459-469. https://doi. org/10.1093/aob/mcr177

Desgroux, A., L'Anthoëne, V., Roux-Duparque, M., Rivière, J. P., Aubert, G., Tayeh, N., ... Pilet-Nayel, M. L. (2016). Genome-wide association mapping of partial resistance to Aphanomyces euteiches in pea. BMC Genomics, 20, 124. https://doi.org/10.1186/s12864-016-2429-4

Didelot, D., \& Chaillet, I. (1995). Relevance and interest of root disease prediction tests for pea crop in France. In AEP (ed.). 2nd European conference of grain legumes. July 9-13th, Copenhagen, Denmark.

Dyer, A. T., \& Windels, C. E. (2003). Viability and maturation of Aphanomyces cochlioides oospores. Mycologia, 95(2), 321-326.

Etxeberria, A., Larregla, S., \& Sorkunde, M. (2011). Determination of viability of Phytophthora capsici oospores with the tétrazolium bromide staining test versus a plasmolysis method. Rebista Iberoamericana De Micologia, 28(1), 43-49.

Frinking, H. D., \& Van der Gaag, D. J. (1996). Extraction from plant tissue and germination of oospores of Peronospora viciae f.sp. pisi. Journal of Phytopathology, 144, 57-62. https://doi.org/ 10.1111/j.1439-0434.1996.tb01489.x

Frinking, H. D., \& Van der Gaag, D. J. (1997). Extraction of oospores of Peronospora viciae from soil. Plant Pathology, 46, 675-679.

Gaulin, E., Jacquet, C., Bottin, A., \& Dumas, B. (2007). Root rot disease of legumes caused by Aphanomyces euteiches. Molecular Plant Pathology, 8, 539-548. https://doi.org/10.1111/j.1364-3703.2007.00413.x

Gentleman, R., \& Ihaka, R. (1996). R: A language for data analysis and graphics. Journal of Computational and Graphical Statistics, 5(3), 299-314

Grau, C. R., Holub, E. B., \& Parke, J. L. (1991). Evaluation of the forma specialis concept in Aphanomyces euteiches. Mycological Research, 95(2), 147-157. https://doi.org/10.1016/S0953-7562(09)81004-6

Grau, C. R., Peters, R. D., \& Shang, H. (2000). Oospore germination of Aphanomyces euteiches in root exudates and on the rhizoplanes of crop plants. Plant Disease, 84, 994-998. 
Greenhalgh, F. C., Merriman, P. R., \& Keane, P. J. (1985). Aphanomyces euteiches, a cause of root rot of subterranean clover in Victoria. Australasian Plant Pathology, 14, 34-37. https://doi.org/10.1071/ APP9850034

Grünwald, N. J., \& Hoheisel, G. A. (2006). Hierarchical analysis of diversity, selfing, and genetic differentiation in populations of the oomycete Aphanomyces euteiches. Phytopathology, 96, 1134-1141.

Hord, M. J., \& Ristaino, J. B. (1991). Effects of physical and chemical factors on the germination of oospores of Phytophthora capsici in vitro. Phytopathology, 81, 1541-1546.

Jiang, J., \& Erwin, D. C. (1990). Morphology, plasmolysis, and tetrazolium bromide stain as criteria for determining viability of Phytophthora oospores. Mycologia, 82, 107-113.

Kraft, J. M., \& Boge, W. L. (1996). Identification of characteristics associated with resistance to roots rot caused by Aphanomyces euteiches in pea. Plant Disease, 80, 1383-1386.

Kraft, J. M., Marcinkowska, J., \& Muehlbauer, J. (1990). Detection of Aphanomyces euteiches in field soil from northern Idaho by a wetsieving/baiting technique. Plant Disease, 74, 716-718. https://doi. org/10.1094/PD-74-0716

Labrousse, F. (1933). Notes de pathologie végétale. Revue De Pathologie Végétale Et D'entomologie Agricole, 19, 71-84.

Lamari, L., \& Bernier, C. C. (1985). Etiology of seedling blight and root rot of Faba bean (Vicia faba) in Manitoba. Canadian Journal of Plant Pathology, 7, 139-145.

Larsen, J., Massfield-Giese, K., \& Bodker, L. (2000). Quantification of Aphanomyces euteuches in pea roots using specific fatty acids. Mycological Research, 149, 487-493.

Lavaud, C., Lesne, A., Piriou, C., Le Roy, G., Boutet, G., Moussart, A., ... Pilet-Nayel, M. L. (2015). Validation of QTL for resistance to Aphanomyces euteiches in different pea genetic backgrounds using near-isogenic lines. Theoretical and Applied Genetics, 128(11), 22732288. https://doi.org/10.1007/s00122-015-2583-0

Le May, C., Onfroy, C., Moussart, A., Andrivon, D., Baranger, A., Pilet-Nayel, M. L., \& Vandemark, G. (2017). Genetic structure of Aphanomyces euteiches populations sampled from United States and France pea nurseries. European Journal of Plant Pathology, 150, $275-$ 286. https://doi.org/10.1007/s10658-017-1274-x

Malvick, D. K., \& Grau, C. R. (2001). Characteristics and frequency of Aphanomyces euteiches races 1 and 2 associated with alfalfa in the midwestern United States. Plant Disease, 85, 740-744.

Malvick, D. K., \& Percich, J. A. (1997). Variation in pathogenicity and genotype among single-zoospore strains of Aphanomyces euteiches. Phytopathology, 88, 52-57.

Moussart, A., Even, M. N., Lesné, A., \& Tivoli, B. (2013). Successive legumes tested in a greenhouse crop rotation experiment modify the inoculum potential of soils naturally infested by Aphanomyces euteiches. Plant Pathology, 62, 545-551.

Moussart, A., Even, M. N., \& Tivoli, B. (2008). Reaction of genotypes from several species of grain and forage legumes to infection with a French pea isolate of the oomycete Aphanomyces euteiches. European Journal of Plant Pathology, 122, 321-333. https://doi.org/10.1007/ s10658-008-9297-y

Moussart, A., Onfroy, C., Lesné, A., Esquibet, M., Grenier, E., \& Tivoli, B. (2007). Host status and reaction of Medicago truncatula accessions to infection by three major pathogens of pea (Pisum sativum) and alfalfa (Medicago sativa). European Journal of Plant Pathology, 117, 57-69. https://doi.org/10.1007/s10658-006-9071-y

Moussart, A., Wicker, E., Duparque, M., \& Rouxel, F. (2001). Development of an efficient screening test for pea resistance to Aphanomyces euteiches. In AEP (ed.). 4th European conference on grain legumes. July 8-12th, Cracow, Poland.

Moussart, A., Wicker, E., Le Delliou, B., Abelard, J. M., Esnault, R., Lemarchand, E., ... Tivoli, B. (2009). Spatial distribution of
Aphanomyces euteiches inoculums in a naturally infested pea fields. European Journal of Plant Pathology, 123(2), 153-158.

Papavizas, G., \& Ayers, W. (1974). Aphanomyces species and their root diseases on pea and sugarbeet. US Department of Agricultural Research Technical Bulletin, 1484, 1-157.

Pfender, W. F., \& Hagedorn, D. J. (1982). Aphanomyces euteiches f.sp.phaseoli, a causal agent of bean root and hypocotyl rot. Phytopathology, 72, 306-310.

Quillévéré-Hamard, A., Le Roy, G., Moussart, A., Baranger, A., Andrivon, D., Pilet-Nayel, M. L., \& Le May, C. (2018). Genetic and pathogenicity diversity of Aphanomyces euteiches populations from pea-growing regions in France. Frontiers in Plant Science, 9, 1673. https://doi. org/10.3389/fpls.2018.01673

Rosendahl, S. (1985). Interactions between the vesicular-arbuscular mycorrhizal fungus Glomus fasciculatum and Aphanomyces euteiches root-rot of peas. Phytopathologische Zeitschrift, 114(1), 31-40.

Scott, W. W. (1961). A monograph of the genus Aphanomyces. Blacksburg, VA: Virginia Agricultural Experiment Station Technical Bulletin.

Shang, H., Grau, C. R., \& Peters, R. D. (2000). Oospore germination of Aphanomyces euteiches in root exudates and on rhiziplanes of crop plants. Plant Disease, 84(9), 994-998.

Sundheim, L. (1972). Physiologic specialization in Aphanomyces euteiches. Physiological Plant Pathology, 2, 301-306. https://doi. org/10.1016/0048-4059(72)90013-6

Tivoli, B., Baranger, A., Sivasithamparam, K., \& Barbetti, M. J. (2006). Annual Medicago: From a model crop challenged by a spectrum of necrotrophic pathogens to a model plant to explore the nature of disease resistance. Annals of Botany, 98, 1117-1128. https://doi. org/10.1093/aob/mcl132

Vandemark, G., Barker, B. M., \& Gritsenko, M. A. (2002). Quantifying Aphanomyces euteiches in alfalfa with a fluorescent polymerase chain reaction assay. Phytopathology, 92, 265-272.

Vandemark, G. J., \& Grünwald, N. J. (2004). Reaction of Medicago truncatula to Aphanomyces euteiches race 2. Archives of Phytopathology and Plant Protection, 37, 59-67.

Vandemark, G., \& Grunwald, N. J. (2005). Use of real-time PCR to examine the relationship between disease severity in pea and Aphanomyces euteiches DNA content in roots. European Journal of Plant Pathology, 111, 309-316. https://doi.org/10.1007/s10658-004-4170-0

Wicker, E. (2001). Diversité des populations françaises d'Aphanomyces euteiches Drechs, agent de la pourriture racinaire du pois: variabilité pathogène et moléculaire. Thèse de doctorat en Sciences biologiques fondamentale et appliquées, agronomie, sciences du sol et production végétale. Rennes: ENSA, 402.

Wicker, E., Hulle, M., \& Rouxel, F. (2001). Pathogenic characteristics of isolates of Aphanomyces euteiches from pea in France. Plant Pathology, 50, 433-442. https://doi.org/10.1046/j.1365-3059.2001.00590.x

Widmer, T. L. (2010). Phytophthora kernoviae oospore maturity, germination, and infection. Fungal Biology, 114, 661-668. https://doi. org/10.1016/j.funbio.2010.06.001

How to cite this article: Billard E, Quillévéré-Hamard A, Lavaud C, Pilet-Nayel ML, Le May C. Testing of life history traits of a soilborne pathogen in vitro: Do characteristics of oospores change according the strains of Aphanomyces euteiches and the host plant infected by the pathogen? J Phytopathol. 2019;00:1-8. https://doi.org/10.1111/ $\underline{\text { jph.12799 }}$ 